\title{
Analysis of GPS trajectories to assess spatio-temporal differences in grazing patterns and land use preferences of domestic livestock in southwestern Madagascar
}

\author{
Tobias Feldt and Eva Schlecht*
}

\begin{abstract}
In order to investigate spatial and temporal characteristics of the purely grazing-based livestock husbandry system in southwestern Madagascar, individual animals from 12 cattle and 12 goat herds that were equally distributed across four villages were fitted with GPS tracking collars and their behaviour during pasturing was directly observed to identify seasonal variations in land use and movement patterns along the regional altitude and vegetation gradient. Monitoring occurred at regular intervals of two months over a two-year period to capture inter-annual variability.

Herds of both species from the inland limestone plateau covered longer distances and were found further away from their home corrals than those from the coastal plain. Patterns of feeding behaviour and utilization of grazing areas mostly reflected the spatial occurrence of specific land cover classes around the villages and differed significantly between seasons and sites. Seasonal water shortage was one of the key factors affecting dry season livestock movements on the plateau but played a minor role in the coastal plain where livestock keeping proved to be more limited by feed availability.

While on transhumance, mobile cattle herds were vulnerable to disadvantages such as limited access to pastureland and water sources nearby their temporary homesteads. The recent problem of armed cattle raids along with emerging land use conflicts compel livestock owners to utilize fewer grazing areas, which threatens to destabilize the region's animal husbandry system.
\end{abstract}

Keywords: Animal husbandry, Cattle raiding, GPS tracking, Grazing itineraries, Seasonality, Transhumance

\section{Introduction}

In many pastoral dryland systems, mobility is the key approach to cope with seasonal environmental variation (Adriansen 2008; Niamir-Fuller 1999a; Turner et al. 2014). Depending on the spatial and temporal availability of important resources such as water and high-quality pastures, livestock farmers have to adjust herding strategies to ensure their livelihood (Little and McPeak 2014; Vetter 2005), whereupon social networks and herders'

\footnotetext{
* Correspondence: schlecht@uni-kassel.de

Section Animal Husbandry in the Tropics and Subtropics, University of Kassel and Georg-August-Universität Göttingen, Steinstrasse 19, 37213 Witzenhausen, Germany
}

\section{Springer}

(c) 2016 Feldt and Schlecht. Open Access This article is distributed under the terms of the Creative Commons Attribution 4.0 International License (http://creativecommons.org/licenses/by/4.0/), which permits unrestricted use, distribution, and reproduction in any medium, provided you give appropriate credit to the original author(s) and the source, provide a link to the Creative Commons license, and indicate if changes were made.
Turner and Hiernaux 2002). Today, it is largely recognized that mobility and seasonal migration of pastoral herds have to be maintained and re-legitimized to preserve the efficiency of these extensive livestock systems (Krätli et al. 2014, 2015; Niamir-Fuller 1999a) which play an important role for food security and well-being of the rural poor in many developing countries (Randolph et al. 2007). However, constraints of anthropogenic origin such as insecurity, banditry, and farmer-herder conflicts further limit mobility and livestock activities (Schilling et al. 2012; Swallow 1994; Turner et al. 2014). 
In Madagascar, livestock and in particular cattle husbandry plays a significant role for the national economy, with more than half of the island's land surface consisting of natural pastures or artificial meadows (FAOSTAT 2014). The country's population of cattle, primarily composed of Small East African zebus (Bos indicus) and to a lesser extent Bos taurus breeds and crossbreeds, was estimated at 10 million in 2013 (FAOSTAT 2014) and is mostly found in the western and southern parts of the island where the animals are of particular social importance to their owners (Rasambainarivo and Ranaivoarivelo 2006). Goats and sheep are less common across the country because of local taboos on respective meat consumption and are mainly concentrated in the dry south and southwest (FAO and AGAL 2005). Hence, this region is still renowned for its big herds of extensively farmed zebu cattle and small ruminants even though the numbers have been declining recently due to general increases in violent crime and acts of cattle raids in the countryside (Rasambainarivo and Ranaivoarivelo 2006). At the same time, the southern region is one of the country's economically and climatically most disadvantaged. It hardly offers any alternative sources of income apart from agricultural production which again suffers from low rainfall with high interannual variability (Jury 2003; Wüstefeld 2004). Although local pastoralists developed appropriate measures to deal with these ecological uncertainties, their traditional herding practices are nevertheless threatened to an increasing degree by access restrictions to potential pasture resources due to expanding private land ownership and the designation of protected areas, which are turning traditional grazing land and migration corridors into no-go areas for livestock (Toutain et al. 2004).

In southwestern Madagascar, the incidence of armed raids for sale of rustled livestock, particularly cattle, on national and regional markets has increased since the coup d'état in 2009 and is greatly excessing the local tradition and male ritual of stealing single animals. Despite Madagascar's return to a democratically elected government in 2014, the security situation in the countryside has not yet improved. The new 'commercialization of cattle raiding' (Leff 2009) disturbs herd mobility, with pastoralists progressively grazing their animals in vicinity to settlements or in regions that are not easily accessed by strangers. Decreasing mobility, as a consequence of insecurity, is threatening rangeland productivity, as has been saliently described by a Maasai elder: when pastoralists are limited in their access to (a few) grazing areas, such areas are overgrazed in semi-arid lands (ISS 2010). The adverse relationship between decreasing security and declining livestock mobility was the framework against which this study aimed to evaluate herd management and spatio-temporal patterns of livestock movement and grazing activity, as well as the resulting utilization of pasture areas and water resources in the Mahafaly region of southwestern Madagascar.

\section{Study area \\ Materials and methods}

The present study was carried out in the northern part of the calcareous Mahafaly Plateau and its adjacent coastal plain. The study region ${ }^{1}$ stretches south from Toliara, the administrative centre of southwestern Madagascar, between the Onilahy and Linta Rivers. It is characterized by arid to semi-arid climatic conditions with an annual mean temperature of $24{ }^{\circ} \mathrm{C}$ and irregular rainfall between $<350$ and $500 \mathrm{~mm}$ per year (Ministère de l'Environnement et Association Nationale pour la Gestion des Aires Protégées 1999), with high small-scale variation especially during the wet season (Hanisch et al. 2015). The dry season usually lasts from April to November but is regularly extended until mid- to late December by absent rainfall events leading to an increased risk of famine (Wüstefeld 2004). The area is part of the Spiny Forest Ecoregion (Fenn 2003) and characterized by a high biodiversity and a high level of endemism in animals but in particular plants (Goodman and Benstead 2003). Most of this biodiversity is conserved within the Tsimanampetsotsa National Park (Ministère de l'Environnement et Association Nationale pour la Gestion des Aires Protégées 1999) and remaining small patches of sacred forests (Tengö et al. 2007). In other parts of the region, a rapidly growing human population, with an annual increase of $3 \%$ within the last 20 years and $3.5 \%$ within the last 5 years (INSTAT 2014), and a rising tendency for 'clandestine pioneer-agriculture' enhances the pressure on natural resources (Brinkmann et al. 2014).

The study region can roughly be divided into two general landscapes - a coastal plain at sea level on sandy soil dominated by loose patches of silver thicket (Euphorbia stenoclada Baill.) between xerophytic shrub thickets (Razanaka 1996) and, after a gentle rise in altitude further inland, a limestone plateau of $330 \mathrm{~m}$ above sea level ( $\mathrm{m}$ a.s.l.) at maximum covered with open landscapes on rocky calcareous substrates and savanna-like grasslands dominated by Heteropogon contortus (L) P.Beauv. ex Roem. \& Schult. and Aristida spp. (Morat 1973), occasionally interspersed by dense bush- and woodland. The sparsely populated area is mainly inhabited by Mahafaly and Tanalana people. Both can be described as agropastoral societies with a traditional focus on animal husbandry and small-scale agriculture (Battistini 1966; Kaufmann 2004). The animal husbandry system in the whole region is constrained by seasonal water and forage shortage (Feldt 2015). While the former mainly affects livestock owners from the plateau area in the course of 
the dry season, the latter is a bigger problem in the coastal plain. To cope with these problems, Tanalana herders from the coastal zone temporarily move their zebu cattle and, in exceptional cases, small ruminants to the plateau to take advantage of the earlier onset of rains in the upland area and the consequent sprouting of grasses. This traditional form of transhumance conventionally lasts for several months before the herds return to their home ranges in the coastal plain.

\section{Data collection}

The present study was carried out with livestock herds from four villages - Ankilibory $\left(23^{\circ} 54^{\prime} \mathrm{S}, 43^{\circ} 41^{\prime} \mathrm{E}\right.$; $18 \mathrm{~m}$ a.s.l.) and Efoetse (24 $04^{\prime} \mathrm{S}, 43^{\circ} 42^{\prime} \mathrm{E} ; 17 \mathrm{~m}$ a.s.l.) located on the coastal plain as well as Andremba $\left(23^{\circ}\right.$ $58^{\prime} \mathrm{S}, 4^{\circ} 12^{\prime} ; 273 \mathrm{~m}$ a.s.l.) and Miarintsoa $\left(23^{\circ} 50^{\prime} \mathrm{S}\right.$, $44^{\circ} 06^{\prime} \mathrm{E} ; 183 \mathrm{~m}$ a.s.l.) on the limestone plateau (Figure 1). The two sites ${ }^{1}$ and four villages ${ }^{1}$, respectively, were selected based on the results of a foregoing baseline survey (Projet SuLaMa 2011), the willingness of livestock keepers to participate in the study, and the feasibility of access. According to Neudert et al. (2015), all villages show a community structure typical for this region with Ankilibory, Efoetse, and Miarintsoa being exclusively inhabited by Tanalana people, while the population of Andremba consists of Tanalana and Mahafaly in equal shares (Table 1 ).

Between November 2011 and November 2013, one adult female individual each from three representative herds of zebu cattle and of goats per village was fitted with a GPS tracking collar (GPS PLUS Store On Board, Vectronic Aerospace GmbH, Berlin, Germany). It recorded the diurnal grazing movements and spatial distribution patterns of the animal by logging the geographical position every $30 \mathrm{~s}$ over three consecutive days at bi-monthly intervals. In the meantime, the collars were removed and utilized in the other villages. Sheep, although also present, were not selected as this species was of minor importance for the local animal husbandry system compared to goats. Experimental animals were

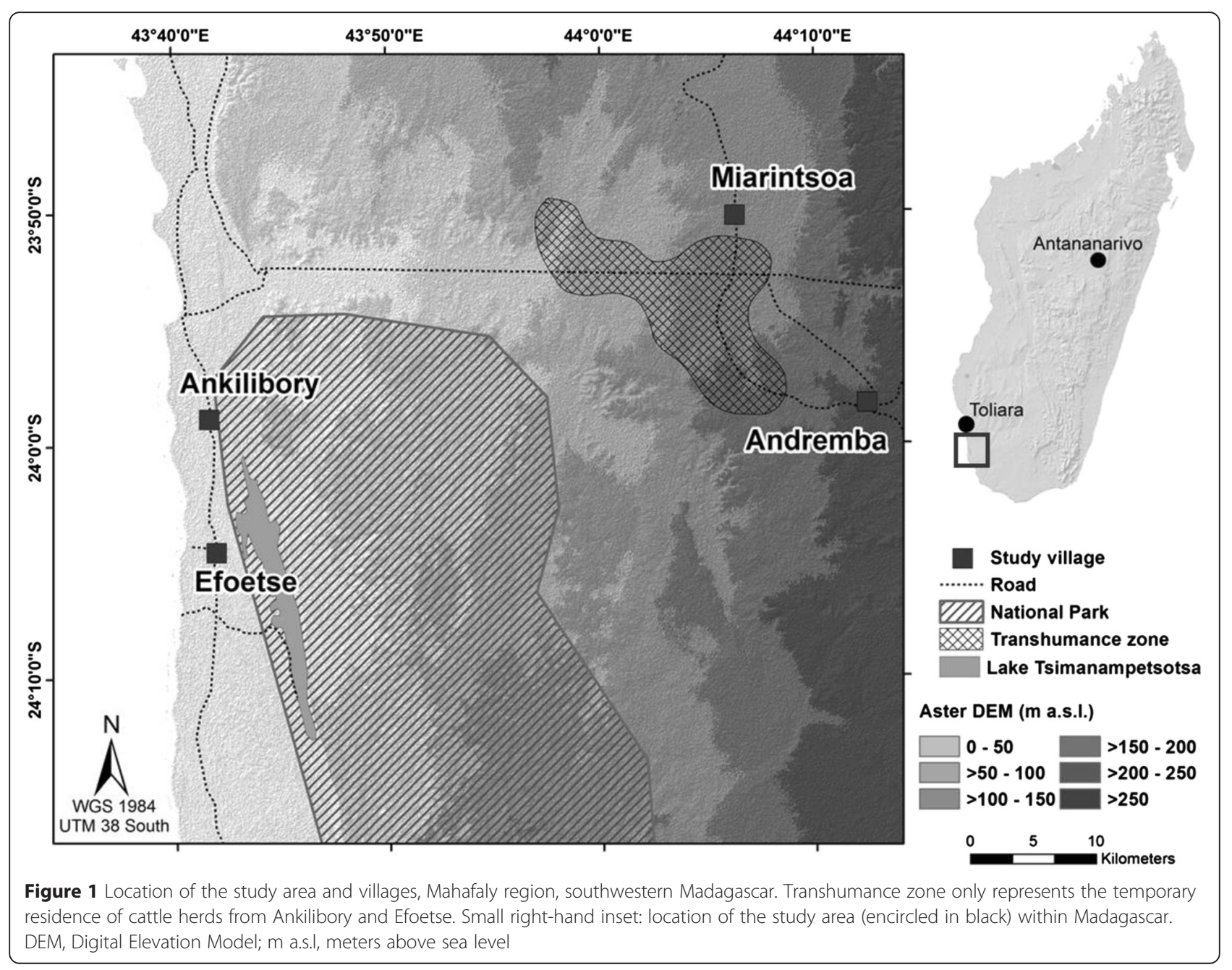


Table 1 Major characteristics of the four study villages - Ankilibory, Efoetse, Andremba, and Miarintsoa

\begin{tabular}{|c|c|c|c|c|}
\hline \multirow[b]{2}{*}{ Village } & \multicolumn{2}{|l|}{ Coast } & \multicolumn{2}{|l|}{ Plateau } \\
\hline & Ankilibory & Efoetse & Andremba & Miarintsoa \\
\hline Altitude ( $m$ a.s.l.) & 18 & 16 & 273 & 183 \\
\hline Mean annual precipitation $(\mathrm{mm})^{1}$ & $\mathrm{n} / \mathrm{a}$ & $220.5^{\mathrm{a}}$ & $451.2^{\mathrm{a}}$ & $635.2^{\mathrm{b}}$ \\
\hline Population, total $(2012)^{2}$ & 748 & 1,294 & 1,048 & 633 \\
\hline Households, total $(2012)^{2}$ & 125 & 216 & 175 & 106 \\
\hline TLU*, 2 & 743 & 1,713 & 1,032 & 641 \\
\hline Study herd sizes, cattle $(n=12)^{c}$ & $36 \pm 2.6$ & $33 \pm 3.9$ & $32 \pm 2.4$ & $40 \pm 3.0$ \\
\hline Study herd sizes, goats $(n=11)^{c}$ & $21 \pm 3.3$ & $41 \pm 4.5$ & $31 \pm 4.7$ & $43 \pm 3.2$ \\
\hline Village pasture area $\left(\mathrm{km}^{2}\right)$ & 102.8 & 79.8 & 144.8 & 109.9 \\
\hline Available water sources for livestock (thereof permanent) & $7(7)$ & $6(5)$ & $6(1)$ & $2(0)$ \\
\hline
\end{tabular}

m a.s.l., meters above sea level; n/a, not available. ${ }^{*}$ TLU Tropical Livestock Units (cattle: 0.7 TLU, goats: 0.1 TLU). ${ }^{1}$ Hanisch, unpubl. data; ${ }^{2}$ Neudert, unpubl. data. ${ }^{a}$ Mean value $2012+2013$; ${ }^{b} 2013$ only; ${ }^{c}$ Mean values for study herds 2011 to $2013 \pm$ standard errors

chosen from the middle social rank to ensure the representability of their mobility and feeding patterns for the whole herd (Moritz et al. 2012). Additionally, each collared animal was followed by an observer on one of the three observation days and its activities were monitored by visual observation every five minutes. Monitoring started in the early morning (usually between 5:30 and 6:30 a.m.) when the animals left their corral (kialo) until they came back in the evening (usually between 6:00 and 7:00 p.m.). Geographic positions of all visited temporal and perennial water points were recorded at the same occasion using a handheld GPS unit (Garmin eTrex, Garmin Ltd., Olathe, KS, USA). The survey was occasionally interrupted when some of the herds returned to their village enclosure during lunch break.

\section{Data analysis}

\section{General aspects}

A total raw data set of 787 daily GPS trajectories $\left(n_{\text {cattle }}=418, n_{\text {goats }}=369\right)$ and 293 direct observations $\left(n_{\text {cattle }}=145, n_{\text {goats }}=148\right)$ entered into analysis. These numbers were slightly lower than expected from the experimental setup as especially goat collars occasionally ran out of battery during use and, in rare cases, the herd owner or his animals were not present when the collars were to be placed, so the herd movements could not be recorded. One goat herd from Ankilibory differed considerably from all others as the tracked animal turned out to be the only adult member of its flock, exclusively ranging within the limited village area accompanied by its recent offspring and mostly feeding on crop residues, which was not the case for the other study herds. Thus, these data were not included in the analysis.

Each study year was divided into three seasons corresponding to the calendar of the local population (Projet SuLaMa 2011; Ranaivoarivelo and Milleville 2001).
During the hot and wet rainy season asara (RS), lasting from December to mid-April, the region receives most of its annual rainfall. Water and food supply for humans and livestock is best at this time of the year. Late single rainfall events may still occur in the course of the cooler early dry season asotry (EDS) which lasts until July, when temporary water holes start to vanish, while there is hardly any precipitation during the hot late dry season afaosa (LDS). Especially on the limestone plateau, access to water is then limited to a few permanent sources (Table 1) and living conditions for people and livestock are the most difficult.

\section{Processing of GPS and GIS data}

GPS recordings of individual daily tracks were corrected for outliers and missing data and then converted from the original geographic coordinate system to a UTM grid projection (WGS1984, zone 38S) using ArcGIS 10.0 (ESRI, Redlands, CA, USA). Line shapes were created from primary point files to measure the total distance of every daily trajectory (walking dist), while the furthest (maximum) distance of a herd from its night enclosure (max_dist) and the linear distance between the corral and the nearest visited water hole during that specific grazing day (dist_water) were calculated using the Near Analysis Tool to depict seasonal variation in water availability. Total daily time on pasture, defined as time outside the enclosure and later referred to as duration, resulted either from direct observation or by subtracting track points which, according to the GIS, were located within the herd's corrals.

To analyse the animals' visit frequency of certain land cover classes (LCC), we used an up-to-date digital land cover classification map (Brinkmann et al. 2014). For the purpose of this study, similar land use categories, such as dry spiny forest thicket and open spiny forest, were merged into one category (here: 
spiny forest and thicket), and one additional class, settlement area, was defined. This resulted in a total of six LCC (Table 2).

The total number of track points per species and observation period was calculated for each LCC. Next, all tracks belonging to herds from the same village that had been measured over the study period were merged and the maximum furthest distance from the settlement centre was taken as the radius which defined the total available pasture area of each individual village. A further buffer of 50-m width was finally created on either side of every daily grazing route to delimit the grazing utilization zone for each herd (Samuels et al. 2007; Schlecht et al. 2009).

Direct observation data were classified into three major activity categories consisting of resting (including immobile times of rumination and social interactions such as nursing), feeding (including grazing, browsing, and drinking), and walking (without feeding). Other social activities, such as fighting, were also recorded, but their share was negligible. Based on the timing of each activity, the observation data was linked to the corresponding geographic information in the GPS-derived data set (coordinates) and transferred to the digital land cover map. This allowed relating the daily duration of each activity to the total time passed in each LCC.

The outcome of the GIS-based data analysis was subsequently crosschecked with the broader results of participatory herder interviews conducted in 2012 and 2014, using a map-based approach suggested by Turner and Hiernaux (2002). In November 2012, a total of 395 herders of cattle and small ruminants were encountered at the three major water points on the limestone plateau. Each herder was asked to depict his regular pasture grounds both in the LDS and during the rest of the year on a field map that delineated water points, land use features, paths, and settlements. A similar but more detailed questioning was conducted in July and August
2014 when six cattle herd owners each from the four focal villages were randomly selected and asked to show on similar maps their herds' pasture grounds during the RS, the EDS, and the LDS. To obtain more information about the impact of the regional (in)security situation on herd management, this mapping exercise was performed for two scenarios - a 'normal' year and a 'bad' year assuming an increased activity of cattle raiders.

\section{Statistical analysis}

Statistical data analyses were performed using SPSS Statistics 20.0.0 (IBM Corp., Armonk, NY, USA), adopting a significance level of $p \leq 0.05$. To avoid pseudoreplication, individual tracks and recordings were pooled per herd for every three-day survey cycle. This resulted in a total number of 146 cattle and 143 goat data sets which were grouped by season. Data residuals were first checked for normal distribution, investigating the skewness and kurtosis $z$-values as well as the Shapiro-Wilk test $p$ value, before testing for homogeneity of variance. Pairwise comparisons of means were then carried out using the independent $t$-test and one-way ANOVA with Tukey post hoc test for normally distributed as well as the Mann-Whitney $U$ and Kruskal-Wallis test for nonnormally distributed data sets in case of two and more than two independent variables, respectively. Welch's $t$ test was used for cases of unequal group variances or sample sizes. All results were specified as mean \pm standard error. Statistical analyses were computed to determine the effect of site $(n=2)$, season $(n=3)$, and species $(n=2)$ on the three itinerary characteristics (walkingdist, max_dist, dist_water), daily time on pasture (duration), and activity patterns, respectively. As the number of animals per herd did not remain stable over the investigation period, Pearson's coefficients $\left(r_{p}\right)$ were calculated to illustrate potential correlations of herd size against characteristics of grazing trajectories (walkingdist, max_dist, dist_water) and duration, respectively.

Table 2 Land cover classes (LCC) and their absolute $\left(\mathrm{km}^{2}\right)$ and proportional (\%, values in brackets) area distribution within the grazing utilization zones of Andremba, Ankilibory, Efoetse, Miarintsoa, and the transhumance zone of coastal cattle herds (C-T)

\begin{tabular}{|c|c|c|c|c|c|c|}
\hline \multirow[t]{2}{*}{ LCC } & \multirow[t]{2}{*}{ Class name } & \multicolumn{2}{|l|}{ Coast } & \multicolumn{3}{|l|}{ Plateau } \\
\hline & & Ankilibory & Efoetse & Andremba & Miarintsoa & $C-T$ \\
\hline I & Open area and loose shrubland & $80.6(78.4)$ & $61.5(77.1)$ & $61.9(42.7)$ & $7.6(6.9)$ & $36.7(14.4)$ \\
\hline$\|$ & Savanna and productive grassland & $0.4(0.4)$ & $0.1(0.2)$ & $6.1(4.2)$ & $32.2(29.3)$ & $30.9(12.1)$ \\
\hline III & Wooded savanna & $0.1(0.1)$ & $<0.1(<0.1)$ & $51.3(35.5)$ & $41.0(37.3)$ & $85.7(33.5)$ \\
\hline IV & Spiny forest and thicket & $14.9(14.5)$ & $2.6(3.2)$ & $15.6(10.7)$ & $11.6(10.5)$ & $91.1(35.6)$ \\
\hline V & Cultivated and abandoned cropland & $6.4(6.2)$ & $15.1(18.9)$ & $9.7(6.7)$ & $16.9(15.4)$ & $10.9(4.1)$ \\
\hline $\mathrm{Vl}$ & Settlement area ${ }^{a}$ & $0.4(0.4)$ & $0.5(0.6)$ & $0.2(0.2)$ & $0.6(0.6)$ & $0.7(0.3)$ \\
\hline \multicolumn{2}{|c|}{ Total area mapped $\left(\mathrm{km}^{2}\right)$} & 102.8 & 79.8 & 144.8 & 109.9 & 256.0 \\
\hline
\end{tabular}

${ }^{a}$ Including livestock enclosures. Reference: adapted from Brinkmann et al. (2014) $\rightarrow$ LCC I = Brinkmann-Class $1+2+3+6, \mathrm{LCC} \mathrm{II}=\mathrm{Cl} .4+10, \mathrm{LCC}$ III $=\mathrm{Cl}$. 5, LCC IV $=$ Cl. $7+8+9, \mathrm{LCC} \mathrm{V}=\mathrm{Cl}$. 10, LCC VI= additional class 
Correlations were also computed between walking dist and dist_water to verify if the availability of water sources had an effect on the length of daily itineraries.

\section{Results}

\section{Site-specific differences in herd management}

Within the research area, cattle and goats were kept and herded separately even if a person owned both species. Thus, joint grazing on pastures only occurred on occasion. The animals were exclusively herded by boys and young men, approximately up to the age of 18 , with the youngest herders (5 to 10 years) normally taking care of the goats. Although it was initially planned to work with flocks of similar size, the number of animals within a herd varied a lot between two consecutive surveys, doubling or halving in some cases ${ }^{2}$. During the study period, the average size ( \pm standard error) varied between $32( \pm 2.4)$ in Andremba and $40( \pm 3.0)$ in Miarintsoa for monitored cattle herds and between $21( \pm 3.3)$ in Ankilibory and $43( \pm 3.2)$ in Miarintsoa for goats.

Most herds were corralled in the village area overnight, but some could also be found in small, temporarily inhabited hamlets or separated enclosures up to $5 \mathrm{~km}$ away. While on the limestone plateau, this small-scale herd displacement mostly occurred during the rainy season, and single herds of both species were almost permanently kept outside the residential area in the coastal zone. Especially during the LDS, some cattle owners from Ankilibory and Efoetse left their animals on their own over longer periods of time without herding and night corralling. Some of these herds entered the Tsimanampetsotsa National Park where grazing is officially prohibited, ranging freely and being only occasionally visited by a herder who would roughly know about the animals' habitual itineraries. This herding strategy was not observed on the plateau side of the study area due to the risk of cattle raids.

In both observation years, transhumance from the coastal plain to the limestone plateau started between late December and early January, with herders leading their cattle from Ankilibory and Efoetse to neighbouring destination areas on the plateau at about $45 \mathrm{~km}$ from the home village. This transhumance movement took one or two days. In the destination area, the animals were kept in corrals which remained unused for the rest of the year. The timing of departure, the migration routes, and the target villages or hamlets were clearly determined by family relations and kinship. From the six study herds practising transhumance, five already returned to their home territories after spending only a few weeks on the plateau, due to the increasing risk of cattle raids towards the end of the rainy season when long-distance pathways across the plateau were again passable and thus better accessible for thieves. This menace was generally regarded to be much lower in the coastal plain. In both observation years, only one cattle owner from Miarintsoa sent his herd to the coastal region in the course of the dry season. Apart from these yearly east-west herd movements between the two survey regions, individual herds of both cattle and goats also temporarily moved in a north-south direction towards areas about 10 to $30 \mathrm{~km}$ away from their home location to gain access to better feeding resources. However, such movement patterns, but also individual herd management characteristics, were too variable to justify the grouping of respective herds into subcategories for analysis.

\section{Characteristics of grazing itineraries}

On average, cattle herds spent 11.0 to $12.9 \mathrm{~h} \mathrm{~d}^{-1}$ on the pasture with significant differences between seasons $(p<0.001)$ but not villages (Table 3$)$. The longest grazing days occurred during the LDS and the shortest in the EDS across all villages (Additional file 1: Figure S1). As shown in Figure 2, herds travelled the longest ways $\left(13.8 \pm 2.8 \mathrm{~km} \mathrm{~d}^{-1}\right)$ during the RS, with transhumant cattle covering the furthest distances. A value of $23.2 \mathrm{~km}$ on one single day was recorded for a herd from Ankilibory in the course of its stay on the plateau, which was the longest daily track during the whole observation period. Transhumant cattle were also found furthest away from their corral (max_dist $=4.4 \pm 1.2 \mathrm{~km} \mathrm{~d}^{-1}$ ) and thus very clearly differed from resident herds (Additional file 1: Figure S2). Across sites, the total mean walking dist was $11.8 \pm 2.5 \mathrm{~km} \mathrm{~d}^{-1}$ in the LDS and $10.7 \pm 1.4 \mathrm{~km} \mathrm{~d}^{-1}$ in the EDS. Plateau herds differed significantly from coastal ones with regard to max_dist $(p<0.01)$ and dist_water $(p<0.001$; Additional file 1: Figure S3), whereby the latter variable also showed distinct seasonal fluctuation $(p<0.01)$. Herd size did not correlate with walking_dist, max_dist, and dist_water across regions. Yet, a correlation existed with dist_water during the EDS $\left(r_{p}=0.72, n=20, p<0.001\right)$ and RS $\left(r_{p}=0.72, n=10, p<0.05\right)$ when analysing the data from the coastal herds separately.

In the case of goat herds, duration ranged between 9.1 and $10.4 \mathrm{~h} \mathrm{~d}^{-1}$, differing significantly between seasons $(p<0.001)$ but not between villages (Additional file 1: Figure S1). Average walking_dist (Table 4) again differed significantly between seasons $(p<0.001)$ and between the two sites of the study area $(p<0.001)$. In contrast to cattle herds, itineraries of goats were longer in the LDS $\left(12.3 \pm 2.2 \mathrm{~km} \mathrm{~d}^{-1}\right)$ than in the RS $\left(10.7 \pm 1.5 \mathrm{~km} \mathrm{~d}^{-1}\right)$ and EDS $\left(9.7 \pm 1.5 \mathrm{~km} \mathrm{~d}^{-1}\right)$ across all four villages (Figure 2). The longest daily track for plateau goat herds was $24.7 \mathrm{~km}$, thus exceeding the maximum grazing distance measured for cattle. In comparison, goats from the 
Table 3 Characteristics of the daily grazing itineraries of cattle and their activities on pasture. The number of tracks results from pooling individual herd data per three-day survey period. Italic values indicate standard errors of the mean

\begin{tabular}{|c|c|c|c|c|c|c|c|c|c|}
\hline \multirow[t]{2}{*}{ Season } & \multirow[t]{2}{*}{ Village } & \multirow{2}{*}{$\begin{array}{l}\text { Tracks } \\
\text { (n) }\end{array}$} & \multicolumn{4}{|c|}{ Itinerary characteristics } & \multicolumn{3}{|c|}{ Daily activity time (\%) } \\
\hline & & & walking_dist (km/d) & max_dist $(\mathrm{km} / \mathrm{d})$ & dist_water (km/d) & Duration $\left(\mathrm{h} \mathrm{d}^{-1}\right)$ & Resting & Feeding & Walking \\
\hline \multirow[t]{5}{*}{$\overline{\mathrm{EDS}}$} & AK & 10 & $9.8^{\mathrm{ab}}$ & $2.7^{\mathrm{ab}}$ & $1.5^{\mathrm{ab}}$ & $11.3^{\mathrm{a}}$ & $8.5^{\mathrm{a}}$ & $69.3^{\mathrm{a}}$ & $22.2^{\mathrm{a}}$ \\
\hline & EF & 12 & $9.0^{\mathrm{a}}$ & $1.9^{\mathrm{a}}$ & $0.4^{\mathrm{ab}}$ & $11.0^{\mathrm{a}}$ & $9.5^{\mathrm{a}}$ & $66.4^{\mathrm{a}}$ & $24.1^{\mathrm{a}}$ \\
\hline & $A D$ & 10 & $11.9^{\mathrm{b}}$ & $3.1^{\mathrm{b}}$ & $2.0^{\mathrm{ab}}$ & $10.6^{\mathrm{a}}$ & $7.9^{\mathrm{a}}$ & $66.9^{\mathrm{a}}$ & $25.2^{\mathrm{a}}$ \\
\hline & $\mathrm{Ml}$ & 10 & $12.2^{\mathrm{b}}$ & $3.2^{\mathrm{b}}$ & $3.1^{\mathrm{b}}$ & $11.2^{\mathrm{a}}$ & $15.8^{\mathrm{a}}$ & $62.5^{\mathrm{a}}$ & $21.7^{\mathrm{a}}$ \\
\hline & & & 0.39 & 0.14 & 0.27 & 0.17 & 1.44 & 1.70 & 1.31 \\
\hline \multirow[t]{5}{*}{ LDS } & AK & 14 & $9.2^{\mathrm{a}}$ & $3.2^{\mathrm{ab}}$ & $1.8^{\mathrm{ab}}$ & $13.6^{\mathrm{a}}$ & $23.6^{\mathrm{a}}$ & $59.3^{\mathrm{a}}$ & $17.1^{\mathrm{a}}$ \\
\hline & EF & 15 & $9.5^{\mathrm{a}}$ & $2.2^{\mathrm{a}}$ & $0.7^{\mathrm{a}}$ & $12.4^{\mathrm{a}}$ & $13.5^{\mathrm{a}}$ & $67.1^{\mathrm{a}}$ & $19.4^{a}$ \\
\hline & $A D$ & 15 & $13.9^{\mathrm{b}}$ & $3.5^{\mathrm{ab}}$ & $3.2^{\mathrm{bc}}$ & $12.7^{\mathrm{a}}$ & $15.5^{\mathrm{a}}$ & $68.3^{\mathrm{a}}$ & $16.2^{\mathrm{a}}$ \\
\hline & $\mathrm{Ml}$ & 13 & $14.6^{\mathrm{b}}$ & $3.7^{b}$ & $4.5^{\mathrm{c}}$ & $12.9^{\mathrm{a}}$ & $18.0^{\mathrm{a}}$ & $55.9^{\mathrm{a}}$ & $26.1^{\mathrm{a}}$ \\
\hline & & & 0.47 & 0.18 & 0.31 & 0.19 & 2.15 & 2.40 & 1.48 \\
\hline \multirow[t]{6}{*}{ RS } & AK & 5 & $13.1^{\mathrm{b}}$ & $3.7^{\mathrm{ab}}$ & $1.2^{\mathrm{a}}$ & $12.3^{\mathrm{a}}$ & $10.7^{\mathrm{a}}$ & $66.1^{a}$ & $23.2^{\mathrm{a}}$ \\
\hline & $\mathrm{EF}$ & 6 & $9.4^{\mathrm{a}}$ & $1.9^{\mathrm{a}}$ & $0.7^{\mathrm{a}}$ & $11.6^{\mathrm{a}}$ & $18.0^{\mathrm{a}}$ & $58.8^{\mathrm{a}}$ & $23.2^{\mathrm{a}}$ \\
\hline & $A D$ & 11 & $13.4^{\mathrm{b}}$ & $2.6^{\mathrm{ab}}$ & $1.0^{\mathrm{a}}$ & $12.1^{\mathrm{a}}$ & $24.3^{\mathrm{a}}$ & $56.1^{a}$ & $19.6^{\mathrm{a}}$ \\
\hline & $\mathrm{Ml}$ & 12 & $15.0^{\mathrm{bc}}$ & $2.4^{\mathrm{a}}$ & $2.0^{\mathrm{a}}$ & $12.0^{\mathrm{a}}$ & $12.5^{\mathrm{a}}$ & $64.9^{\mathrm{a}}$ & $22.6^{\mathrm{a}}$ \\
\hline & $C-T$ & 13 & $17.9^{c}$ & $4.4^{b}$ & $1.9^{\mathrm{a}}$ & $12.8^{\mathrm{a}}$ & $6.8^{\mathrm{a}}$ & $66.9^{\mathrm{a}}$ & $26.3^{\mathrm{a}}$ \\
\hline & & & 0.51 & 0.21 & 0.18 & 0.16 & 1.81 & 1.90 & 1.26 \\
\hline Independent variable & & $d f$ & & & & & & & \\
\hline Site & & 1 & $* * *$ & $* * *$ & $* * *$ & n.s. & n.s. & n.s. & n.s. \\
\hline Season & & 2 & $* * *$ & n.s. & $* *$ & $* * *$ & $*$ & n.s. & n.s. \\
\hline
\end{tabular}

walk_dist, total distance of daily trajectories; max_dist, furthest distance of a herd from its night enclosure; dist_water, linear distance between night enclosure and the nearest visited water hole. EDS, early dry season; LDS, late dry season; RS, rainy season. AD, Andremba; AK, Ankilibory; EF, Efoetse; MI, Miarintsoa; C-T, transhumant cattle herds from AK and EF on plateau. ${ }^{a}, \mathrm{~b}$, c Significant differences between means in the same column within one season according to post hoc tests. ${ }^{*} p \leq 0.05,{ }^{* *} p \leq 0.01,{ }^{* * *} p \leq 0.001$, n.s., non-significant

coastal plain never walked more than $14.5 \mathrm{~km} \mathrm{~d}^{-1}$. Throughout the year, max_dist varied between seasons $(p<0.05)$ and was higher for plateau herds than for costal herds $(p<0.001$; Additional file 1: Figure S2). Spatial $(p<0.001)$ and temporal $(p<0.01)$ differences also occurred with regard to dist_water (Additional file 1: Figure S3). Unlike in cattle herds, movement patterns of goats strongly varied with herd size, which was negatively correlated with walking dist $\left(r_{p}=-0.37, n=59\right.$, $p<0.01)$ and positively with duration $\left(r_{p}=0.28, n=\right.$ $59, p<0.05)$ for coastal herds. In contrast, herd size on the plateau was significantly correlated with max_dist $\left(r_{p}=0.30, n=59, p<0.05\right)$ and duration $\left(r_{p}=0.40\right.$, $n=61, p=0.001)$.

Comparing the two livestock species, the daily duration of pasturing was always longer for cattle than for goats across the two sites and three seasons $(p<0.001$ in all cases). Livestock species also differed significantly in walking_dist $(p<0.001)$ and max_dist $(p<0.01)$ on the limestone plateau and for the variables max_dist $(p<0.001)$ and dist_water $(p<0.05)$ in the coastal plain. Across the two sites, cattle covered significantly longer distances than goats in the RS (walking_dist: $p<0.001$, max_dist: $p<0.001$, dist_water: $p<0.01)$; for max_dist, these differences were also significant in the EDS and LDS ( $p<0.05$ in both cases).

\section{Daily behaviour on pasture}

The average proportion of time spent feeding by cattle was $64 \%$ throughout the year. It was followed by $22 \%$ of time spent walking and $14 \%$ resting time with no significant differences between sites and only for resting $(p<0.05)$ between seasons (Table 3$)$. No behaviour monitoring occurred when herds returned to their enclosures for noon resting time. Such midday breaks lasted from 0.8 to $3.7 \mathrm{~h}$ and were longest during the LDS (Additional file 2: Table S1).

Feeding was also the dominant behaviour in goats, accounting for $69 \%$ of the daily observed time, followed by walking ( $23 \%)$ and resting $(8 \%)$. Time allocation did not differ between seasons but was different for resting $(p<0.05)$ and feeding $(p<0.05)$ for plateau versus coastal goat herds (Table 4). Most goat flocks came back to the village for a noon break lasting 1.3 to $2.7 \mathrm{~h}$ during the EDS, 2.0 to $3.4 \mathrm{~h}$ during the RS, and 3.0 to $3.7 \mathrm{~h}$ during the LDS, whereby the duration of these interruptions 


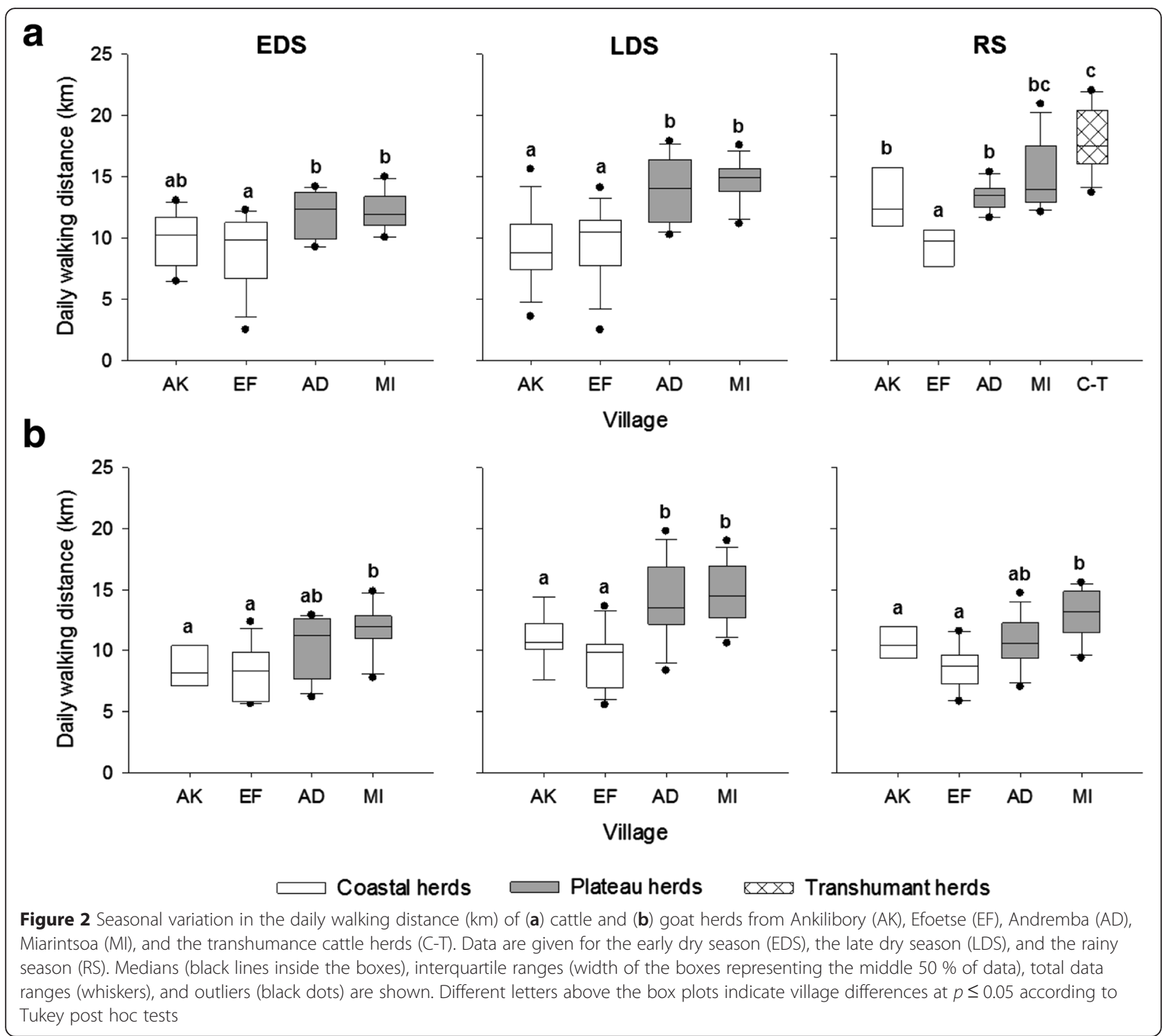

varied more between single villages than between the plateau and the coastal plain (Additional file 2: Table S1).

When comparing goats to cattle, coastal goats spent a significantly higher proportion of time feeding than coastal cattle $(p<0.05)$ but less time resting $(p<0.05)$. The latter was also the case on the limestone plateau $(p<0.001)$. Across the two regions, significant differences $(p<0.05)$ between both species were determined for resting $(p<0.01)$ and feeding $(p<0.001)$ activities in the LDS and for feeding in the RS $(p<0.05)$, whereas no differences were found in the EDS.

\section{Land cover preferences of cattle and goat herds}

Almost all livestock herds showed a highly dispersed pasture use, infrequently visiting the same grazing ground on consecutive days (Additional file 1: Figures S4 to S12). The proportion of daily time on pasture that was allocated to different LCC differed widely between sites $(p<0.001)$ for both livestock species and, to a lesser extent, between seasons for cattle $(p<0.05)$. This is partly a result of the different distributions of the six LCC across each village territory.

Throughout the year, coastal cattle herds predominantly grazed on open area and loose shrubland of E. stenoclada (73\% to $84 \%$ of LCC visited). This LCC was the most abundant around Ankilibory and Efoetse as shown in Figure 3. Relative to their spatial occurrence, a disproportionately high share of feeding time was recorded for cultivated and abandoned cropland and settlement areas throughout the year.

On the limestone plateau, cattle spent a high proportion of feeding time on open area and loose shrubland (Figure 3) around Andremba (34\% to $57 \%$ ) and on wooded savanna ( $24 \%$ to $61 \%$, all herds), as well as on 
Table 4 Characteristics of the daily grazing itineraries of goats and their activities on pasture. The number of tracks results from pooling individual herd data per three-day-survey period. Italic values indicate standard errors of the mean

\begin{tabular}{|c|c|c|c|c|c|c|c|c|c|}
\hline \multirow[t]{2}{*}{ Season } & \multirow[t]{2}{*}{ Village } & \multirow{2}{*}{$\begin{array}{l}\text { Tracks } \\
\text { (n) }\end{array}$} & \multicolumn{4}{|l|}{ Itinerary characteristics } & \multicolumn{3}{|c|}{ Daily activity time (\%) } \\
\hline & & & walking_dist (km/d) & max_dist $(\mathrm{km} / \mathrm{d})$ & dist_water $(\mathrm{km} / \mathrm{d})$ & Duration $\left(\mathrm{h} \mathrm{d}^{-1}\right)$ & Resting & Feeding & Walking \\
\hline \multirow[t]{5}{*}{$\overline{\mathrm{EDS}}$} & $A K$ & 10 & $8.4^{\mathrm{a}}$ & $2.2^{\mathrm{ab}}$ & $1.2^{\mathrm{a}}$ & $9.0^{\mathrm{a}}$ & $8.5^{\mathrm{ab}}$ & $69.3^{\mathrm{a}}$ & $22.2^{\mathrm{a}}$ \\
\hline & EF & 12 & $8.2^{\mathrm{a}}$ & $1.7^{\mathrm{a}}$ & $0.4^{\mathrm{a}}$ & $9.4^{\mathrm{a}}$ & $3.1^{\mathrm{a}}$ & $73.0^{\mathrm{a}}$ & $23.9^{\mathrm{a}}$ \\
\hline & $A D$ & 10 & $10.5^{\mathrm{ab}}$ & $2.6^{\mathrm{ab}}$ & $0.8^{\mathrm{a}}$ & $9.5^{\mathrm{a}}$ & $13.4^{\mathrm{b}}$ & $59.3^{\mathrm{a}}$ & $27.3^{\mathrm{a}}$ \\
\hline & $\mathrm{Ml}$ & 10 & $11.8^{\mathrm{b}}$ & $2.8^{\mathrm{b}}$ & $2.6^{\mathrm{b}}$ & $8.6^{\mathrm{a}}$ & $6.0^{\mathrm{a}}$ & $71.1^{\mathrm{a}}$ & $22.9^{\mathrm{a}}$ \\
\hline & & & 0.42 & 0.14 & 0.21 & 0.22 & 1.33 & 2.01 & 1.40 \\
\hline \multirow[t]{5}{*}{ LDS } & AK & 14 & $11.0^{\mathrm{a}}$ & $1.9^{\mathrm{ab}}$ & $1.1^{\mathrm{a}}$ & $10.2^{\mathrm{a}}$ & $13.1^{\mathrm{a}}$ & $62.9^{\mathrm{a}}$ & $24.0^{\mathrm{a}}$ \\
\hline & EF & 15 & $9.4^{\mathrm{a}}$ & $1.8^{\mathrm{a}}$ & $0.5^{\mathrm{a}}$ & $9.8^{\mathrm{a}}$ & $4.6^{\mathrm{a}}$ & $74.6^{\mathrm{a}}$ & $20.8^{\mathrm{a}}$ \\
\hline & $A D$ & 15 & $14.1^{\mathrm{b}}$ & $3.0^{\mathrm{b}}$ & $1.9^{\mathrm{ab}}$ & $10.8^{\mathrm{a}}$ & $7.0^{\mathrm{a}}$ & $70.3^{\mathrm{a}}$ & $22.7^{\mathrm{a}}$ \\
\hline & $\mathrm{Ml}$ & 13 & $14.6^{\mathrm{b}}$ & $3.6^{b c}$ & $4.7^{\mathrm{b}}$ & $10.3^{\mathrm{a}}$ & $7.0^{\mathrm{a}}$ & $67.9^{\mathrm{a}}$ & $25.1^{\mathrm{a}}$ \\
\hline & & & 0.48 & 0.16 & 0.30 & 0.27 & 1.13 & 1.76 & 1.37 \\
\hline \multirow[t]{5}{*}{ RS } & AK & 5 & $10.4^{\mathrm{a}}$ & $2.0^{\mathrm{ab}}$ & $1.1^{\mathrm{b}}$ & $10.5^{\mathrm{a}}$ & $14.7^{\mathrm{a}}$ & $64.0^{\mathrm{a}}$ & $21.3^{\mathrm{a}}$ \\
\hline & $\mathrm{EF}$ & 6 & $8.7^{\mathrm{a}}$ & $1.6^{\mathrm{a}}$ & $0.3^{\mathrm{a}}$ & $10.3^{\mathrm{a}}$ & $6.3^{\mathrm{a}}$ & $76.0^{\mathrm{a}}$ & $17.7^{\mathrm{a}}$ \\
\hline & $A D$ & 11 & $10.8^{\mathrm{ab}}$ & $2.0^{\mathrm{ab}}$ & $0.9^{\mathrm{ab}}$ & $10.3^{\mathrm{a}}$ & $12.2^{\mathrm{a}}$ & $68.3^{\mathrm{a}}$ & $19.5^{\mathrm{a}}$ \\
\hline & $\mathrm{Ml}$ & 12 & $13.0^{\mathrm{b}}$ & $2.6^{\mathrm{b}}$ & $1.3^{b}$ & $10.5^{\mathrm{a}}$ & $9.4^{\mathrm{a}}$ & $66.7^{\mathrm{a}}$ & $23.9^{\mathrm{a}}$ \\
\hline & & & 0.37 & 0.11 & 0.10 & 0.22 & 1.21 & 1.78 & 1.05 \\
\hline Independent variable & & $d f$ & & & & & & & \\
\hline Site & & 1 & $* * *$ & $* * *$ & $* * *$ & n.s. & $*$ & * & n.s. \\
\hline Season & & 2 & $* * *$ & * & $* *$ & $* * *$ & n.s & n.s. & n.s. \\
\hline
\end{tabular}

open savanna and productive grassland around Miarintsoa and in the transhumance area (13\% to $54 \%$ ). Irrespective of the village, the proportion of feeding time the cattle allocated to a specific LCC varied strongly between seasons $(p<0.001)$. In Andremba, the highest share of feeding time was allocated to the settlement area, especially during the LDS, and to wooded savanna as well as cultivated and abandoned cropland during the RS. In Miarintsoa, the highest share of feeding time was allocated to savanna and productive grassland in the LDS and to open area and loose shrubland as well as wooded savanna in the RS (Figure 3). For LCC visited by cattle during resting and walking, see Additional file 1: Figures S13 and S14.

LCC visited for feeding by goats differed marginally from those of cattle (Figure 4). Significant differences between the two species could only be found for open area and loose shrubland in Efoetse $(p<0.05)$ and for cultivated and abandoned cropland in Ankilibory $(p<0.05)$. There, feeding activity was observed more frequently in goats than could be expected from the spatial extend of the respective LCC. Also, plateau goats from Andremba showed a certain preference for cultivated and abandoned cropland and the settlement area throughout the year, which is indicated by the high proportion of feeding time spent on these LCC as compared to the proportion of total time spent on the respective LCC. Contrastingly, goats in Miarintsoa spent a disproportionately high share of their feeding time on wooded savanna and on the settlement area throughout the year and on savanna and productive grassland during the LDS (Figure 4). For goats' visits of LCC during resting and walking, see Additional file 1: Figures S15 and S16.

\section{Discussion}

Earlier studies on the livestock and especially cattle husbandry system in southwestern Madagascar (Battistini 1966; Kaufmann 1998; Kaufmann and Tsirahamba 2006) mainly focused on the coastal zone or provided a rather general and mainly qualitative analysis of transhumance movements. In particular, the regional conjunction between the availability of pastureland and seasonal migration, that is between areas of departure on and destination of transhumance movements, as well as the influence of rising insecurity through organized cattle raids has so far not been addressed.

Overall, the results indicate a high variation in movement patterns and utilization of LCC between the two sites and even between cattle and goat herds from the same village. Differences in herding strategies, such as in 


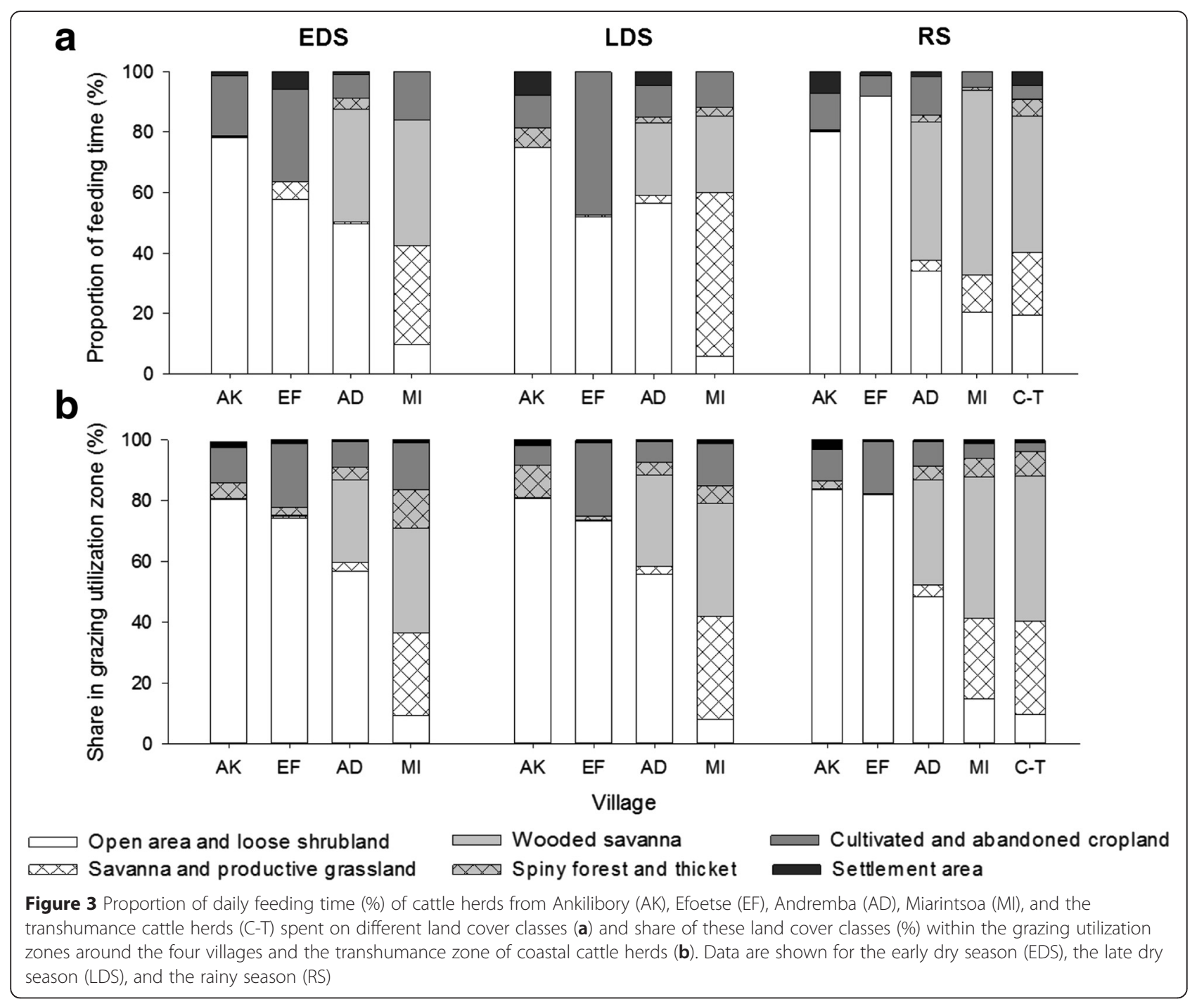

terms of night corralling and free grazing within the national park area, and the different ecological conditions in the coastal zone and on the limestone plateau reinforce the clear divergences between these two sites. The transhumant zebu herds occupied a special position during their time of seasonal migration. The insights into herd management gained through GPS tracking and direct observation of the study herds while blending these data with land cover classifications largely correspond to the outcome of the participatory mapping exercises, even though their results are not shown here.

\section{Spatial and seasonal differences in movement patterns}

The average values of the recorded movement parameters of cattle, and in particular the length of daily trajectories, largely correspond to values reported from similar studies in the Sahel (Schlecht et al. 2006) and East Africa (Butt 2010b). In contrast, the daily distances travelled by goat herds clearly exceeded those measured by Ouédraogo-Koné et al. (2006) in West Africa and Akasbi et al. (2012) in southern Morocco, though the latter obtained his results in a mountainous region where the animals had to spend a substantial part of their energy on vertical movements. During a survey conducted by Rabeniala et al. (2009) in a coastal area north of our study region, flocks of small ruminants only walked between 4.7 and $6.2 \mathrm{~km} \mathrm{~d}^{-1}$ in the rainy season but $13.7 \mathrm{~km} \mathrm{~d}^{-1}$ when visiting a water point in the dry season. However, these results were based on a low number of samples and the length of the animals' itineraries was only occasionally recorded by an observer from a greater distance. Therefore, both studies are not easily comparable. A significantly higher mobility of cattle compared to goats as observed by Turner et al. (2014) could not be confirmed in general terms. For logistic reasons, the present work could not capture night grazing, which might have had a non-negligible effect on the total length of itineraries and the animals' performance 


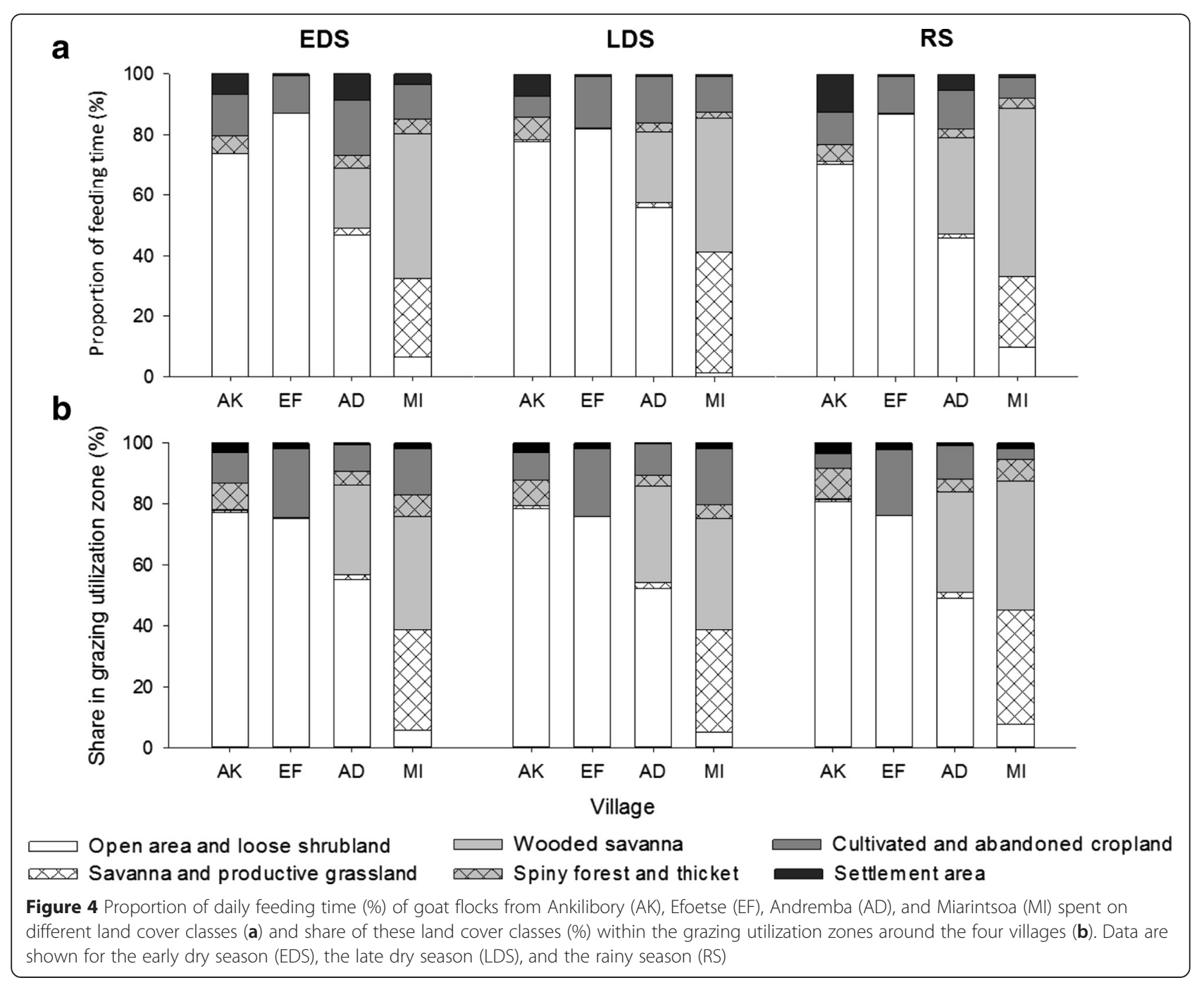

(Ayantunde et al. 2000, 2002). Nocturnal activities occasionally occurred in both sites and were slightly more frequent in the freely roaming coastal cattle herds in the course of the dry season.

Throughout the year, herds of both species had longer itineraries and were found further away from their night enclosures on the limestone plateau than on the coastal plain. This reflects on the one hand the spatial conditions of each site as livestock itineraries in Ankilibory and Efoetse were limited to the west by the sea, to the east by the national park, and in general by a higher density of cultivated areas around coastal villages.

In the course of the dry season, access to water was the key factor driving the movement of plateau herds. Water supply was significantly better near the coast with a broader network of artificial wells and also water holes with connection to groundwater, most of the latter bearing saline but still palatable water for livestock throughout the year. Furthermore, coastal herds were preferentially fed with locally available succulent fodder plants such as prickly pear cactus (Opuntia monacantha Haw.) and E. stenoclada during the dry season, which reduced their need for additional intake of drinking water.

On the plateau, water holes near residential zones fall dry within a few weeks or months after the last rainfall event or, as in Andremba, provide just enough water for humans or small and privileged herds. All other herds are forced to travel sometimes long distances towards the remaining water sources. Most herders tend to lead their animals to water in the morning and to get back near their homesteads before the hottest time of the day. These trajectories often showed the typical characteristics that have been described by several authors in the context of piosphere and central-place models (Andrew 1988; Coppolillo 2001; Thrash and Derry 1999), such as soil compaction by trampling and accumulation of livestock faeces near water points and resting places. 
Despite this long-distance travelling and comparatively shorter grazing days in the dry season, cattle herds covered the longest distances during the rainy season, when water availability was no problem. This contrasts with the results of the vast majority of studies in arid environments, which report the furthest distances travelled in the dry season (Butt 2010b; Ouédraogo-Koné et al. 2006; Schlecht et al. 2006). Especially for the plateau, this divergence may result from the more heterogeneous landscape and stronger seasonal variation of the vegetation in comparison with the coastal site, which offers more choice for selecting pasturing areas with better availability of forage and water and to move the herds more frequently to a new productive grazing ground (Brottem et al. 2014; Little and McPeak 2014; Scoones 1995). In addition, long-distance dry season travel to water points did not occur on a daily basis, but only every two to four days, depending on the water demand of the animals.

In contrast to cattle, seasonal movement patterns of the observed goat herds corresponded well to literature reports. Even though goats were generally managed in a similar manner to zebu cattle, the fact that young boys were primarily responsible for herding this species made a difference, as they got tired more quickly than their older, cattle-guarding counterparts. Therefore, they led the animals back to the village for longer and more regular midday breaks, especially during the rainy season when temperatures are the highest of the year.

The longest daily grazing itineraries and maximum distance values from night enclosure were recorded for transhumant coastal cattle herds which spent a limited period of time on the limestone plateau during the rainy season. This may be explained by the influence of nonenvironmental factors, in particular the economic and social circumstances in their temporal environment, on the mobility strategies of 'outside herders' as suggested by Baker and Hoffman (2006) and Turner et al. (2011). Although Battistini (1966) emphasized the equal rights of coastal herders on plateau pastures dating back to ancient agreements between the respective clans and families, transhumant herds were still only temporary visitors and therefore might, to a certain extent, have had less access to the grazing grounds around their temporal homesteads than the residential herds. At the same time, the migrating herds were free to cross the territorial borders between different villages. Consequently, they would reach more distant pasture areas while the residential herds were restricted to their own village grazing territory and were only allowed to graze on neighbouring grounds in times of severe need (Projet SuLaMa 2011). In both observation years, only one plateau cattle owner from Miarintsoa sent his herd to the coastal region in the course of the dry season. Even though this was the only incident of an 'inverse' transhumance across all studied herds, this apparently new management strategy was regularly reported from Tanalana livestock keepers on the limestone plateau who took advantage of family bonds with coastal residents to avoid the rising security risk in their home area. Sporadically, this 'inverse' transhumance also involved herds of small ruminants.

\section{Spatio-temporal variations in land use}

The intersection of the GPS-tracked grazing itineraries and their buffers, that is, the pasture utilization zones, with the digital land cover data of the GIS proved particularly useful to draw conclusions about the sustainability of the herds' use patterns of land cover types and grazing resources and allowed inferences on the animals' nutritional situation (Schlecht et al. 2006, 2009). Such data can then further be used in conceptualizing and parameterizing agent-based models of pasture utilization, as has recently been shown by Moritz et al. (2015). Yet, such studies are still rare and most authors using GPS/GIS tools in livestock studies content themselves with more general statements about distances or mobility patterns (e.g. Akasbi et al. 2012; Baker and Hoffman 2006; Ouédraogo-Koné et al. 2006).

The land cover preference of cattle and goat herds mostly reflected the spatial occurrence of specific LCC within the pasture areas of each village and therefore quite likely differs from other studies. For example, Tsirahamba and Kaufmann (2008) pointed the importance of spiny forests as zebu pasture for an area just south of the study region, while this LCC was rarely found along the daily itineraries of the monitored herds and therefore was not important for grazing in the present study. At the same time, the herds' land use patterns were closely linked to the seasonal availability of important feed resources and the site-specific composition of the rangeland vegetation. In this regard, Feldt (2015) determined 13 plant species that are of major importance for the animals' nutrition in the Mahafaly region - such as Heteropogon contortus, Panicum voeltzkowii Mez (both graminoids), Solanum hippophaenoides Bitter, and Ziziphus spina-christi (L.) Desf. (both woody plants), as well as Euphorbia stenoclada and Opuntia monacantha (both succulents).

The high feeding time allocation of both cattle and goat herds to arable land was surprising. Usually, livestock is not allowed to enter these zones, especially during the cropping season and violations are usually punished; yet, exceptions are made for draught oxen and smaller flocks of sheep (Fieloux and Rakotomalala 1987). However, our LCC cultivated and abandoned cropland grouped actively managed fields and abandoned ones, since they could hardly be distinguished on satellite images. Especially in the coastal zone, former fields were 
sometimes converted to private pastures which were of great importance for the herds' fodder supply during the dry season. Usually, old living fences composed of cacti and other plants remained around these private pastures, delineating them. At the same time, fallow fields might also have been misclassified as open areas with hardly any vegetation cover (Brinkmann et al. 2014). On the plateau, arable areas are sometimes smoothly but steadily expanding into open savanna, the habitual pasture area. Together with livestock grazing, this continuous expansion of cropland in the study region, that has been documented by Brinkmann et al. (2014) from their analysis of satellite images for the years 2004 and 2013, is considered a major threat for the region's natural vegetation and a major cause of deforestation in southwestern Madagascar (Casse et al. 2004). It also increases the potential for conflicts between crop farmers and livestock keepers due to crop damage as reported from agropastoral societies in other dryland regions (Turner et al. 2014). Transhumant herds are particularly vulnerable to the effects of cropland expansion as this may affect their traditional transhumance corridors and destination areas (Turner et al. 2011).

Especially on the limestone plateau, the avoidance of farmer-herder conflicts was often mentioned by livestock keepers as a reason for temporarily shifting herds of cattle as well as of small ruminants to encampments outside the village during the rainy and early dry seasons, when cropping activities peak and drinking water is abundant. In the coastal plain, in contrast, this sort of micro-mobility of herds (Adriansen 2008) mostly occurred in the course of the dry season in search of better pastures.

The comparatively high proportion of time spent feeding within or around settlement areas in relation to the occurrence of this LCC proved a certain importance of these spots for the animals' nutrition. This was especially true for the herds that were moved back to the villages at noon without being corralled. Many of the animals then ranged around freely and sporadically continued to feed on shrubs and the thin turf growing in between the houses before returning to pasture with their herders for the cooler hours of the afternoon. The same was true when herds came back from long-distance visits to water points in the dry season. For this reason, the areas closest to the livestock keepers' households are likely to be affected most by the animals, consequently showing certain signs of overgrazing as described by Butt (2010a) for the Maasai in Kenya.

\section{Security effects on land use and herd management}

Apart from the already discussed seasonal constraints in water and forage availability and the spatial access restrictions due to ongoing expansion of agricultural land around settlements, as well as the existence of the Tsimanampetsotsa National Park, a steadily increasing risk of livestock raiding emerged to be another important factor influencing the regional herding practices. The outcome of the in-depth herder interviews and scenario games conducted in 2014 along with reports and occasional observations of frequent changes in pasture grounds due to this menace confirmed its influence on the management and the spatio-temporal distribution of livestock herds throughout the area.

The theft of domestic animals and especially zebus has always been an issue for the region's livestock farmers but was traditionally considered a petty crime and a means of providing masculine prowess (Fieloux and Rakotomalala 1987; Hoerner 1982). However, Fauroux (1989a, b) already referred to more organized and violent cattle raids in southwestern Madagascar in the 1940s and 1980s and then even provoked limited military counteractions. Notably in the south of the island, the situation has clearly deteriorated within the past years, reflecting the country's ongoing political and economic crisis (Amnesty International 2013; Fafchamps and Moser 2003; Ignace 2010). Presumably, cattle originating from such raids provided about $30 \%$ to $40 \%$ of meat on the national beef market a decade ago as reported by Fauroux (2004). For a certain time thereafter, the remote study area was not greatly affected by violent livestock theft. However, in the past five years, gangs of sometimes heavily armed cattle raiders (dahalo in High Malagasy or malaso in the southern dialect) have again infiltrated the study region to an increasing degree. Thereby, they clearly have a stronger impact on the more easily accessible and spacious limestone plateau than on the narrower and more densely populated coastal zone where seized cattle herds cannot be easily deported and crime can be prosecuted more successfully.

Local pastoralists have been forced to adapt to this increasingly tense security situation by more frequently changing daily grazing grounds and shifting their cattle to hidden livestock camps outside the settlements. This also includes taking herds on an 'inverse' transhumance towards the safer coastal zones in the course of the dry season (Götter, personal communication). Such riskavoiding strategy, which has also been described by Niamir-Fuller (1999b) for pastoralists in Uganda, is not sufficient to counter the threat of becoming the victim of a raid, though. Transhumant herds from the coastal plain proved to be particularly vulnerable to raids on the plateau during the two years of survey. Several affected transhumant herders were observed to change their grazing grounds and transhumance location in direct response to either actual malaso attacks or rumours of such activities. Most of these herds moved back to their 
coastal home grounds far earlier than originally planned or reported for the past, accompanied by additional cattle herds originating from the limestone plateau which spent the rest of the rainy and parts of the dry season in the supposedly safer region. This trend in turn currently increases the grazing pressure on the scarce vegetation of the coastal plain which, in the past, was able to regenerate during the absence of the transhumant herds in the rainy season. However, since transhumant coastal cattle plus additional plateau herds now tend to come back earlier, the required period of regeneration, especially for the annual herbaceous vegetation on the shallow sandy soils, may not be long enough anymore, with negative consequences for biomass production (Hiernaux et al. 2009) and thus animal nutrition. Furthermore, the potential for conflict with resident crop farmers is also increased by the early return of transhumant herds and especially by the newcomers from the plateau (Swallow 1994; Turner et al. 2011). Herd owners are consequently obliged to violate prohibitions, e.g. by conducting their animals at a progressive rate into the protected zones of the Tsimanampetsotsa National Park for grazing. Rising insecurity may therefore severely alter the system of animal husbandry in the whole region where state authorities have little power and livestock keepers can hardly expect any support from the government.

\section{Conclusions}

The intersection of GPS-tracked grazing routes with digital land cover data proved very useful to quantify patterns of land use and herd movement. In view of the utility of such information for inference on rangeland health and livestock nutrition as well as spatio-temporal modelling of livestock distribution, this approach should be a systematic component of quantitative research on pastoral mobility.

The present comparison of the two geographically clearly separated study sites within the same research area that are however closely linked by the seasonal migration of transhumant cattle herds highlights the clear differentiation in herding strategies and grazing land use according to site-specific constraints. Whereas coastal livestock face limited forage availability in the course of the dry season, leading to an increased mobility to gain access to better pasture grounds, cattle and goat herding strategies on the limestone plateau particularly respond to seasonal water scarcity. Particularly in the dry season, the high risk of cattle raids on the plateau hampers larger-scale mobility of residential and especially of transhumant herds from the coast. As a consequence, pastoralists are forced to relocate their animals to secured areas and to modify their transhumance patterns. This results in negative consequences for the fragile vegetation of the coastal zone and for the protected area of the national park, while at the same time increasing the potential for farmer-herder conflicts in the vicinity of settlements.

\section{Recommendations}

From our analyses, the following suggestions emerge. Firstly, bush hay could be harvested on remote plateau areas that are avoided by herders due to water scarcity or the risk of assaults and could be fed to the livestock kept safely in village confines. This strategy, which is widespread in Sahelian West Africa, is so far not practised by local pastoralists. Secondly, the construction of new water retention basins for plateau livestock herds could prolong the animals' water supply for several weeks or even months in the dry season and could thus delay the travel to distant water sources and the concomitant vulnerability to assaults. Thirdly, systematically planting fodder plants in the coastal plain, in particular cuttage-based forestation of E. stenoclada, could help to counteract the problem of overgrazing. However, to achieve enduring improvements for livestock keepers in southwestern Madagascar, enhancing the overall security in the region is the most crucial. This first and foremost requires political and economic stability at the national level.

\section{Endnotes}

${ }^{1}$ The term 'region' addresses the entire study area, 'site' the plateau and the coastal zone, and 'village' the four settlements.

${ }^{2}$ The reasons for this high variation may be temporary pooling and splitting of herds of closely related family members or aggregation of prior male cattle for ritual purpose before upcoming funeral and wedding ceremonies.

\section{Additional files}

Additional file 1: Figure S1. Seasonal variation in the duration of grazing days ( $\mathrm{h} \mathrm{d}^{-1}$ ) of (a) cattle and (b) goat herds from Ankilibory (AK), Efoetse (EF), Andremba (AD), Miarintsoa (MI), and the transhumance cattle herds (C-T). Data are presented for the early dry season (EDS), the late dry season (LDS), and the rainy season (RS). Medians (black lines inside the boxes), interquartile ranges (width of the boxes representing the middle $50 \%$ of data), total data ranges (whiskers), and outliers (black dots) are shown. Different letters above and underneath the box plots indicate village differences at $p \leq 0.05$ according to Tukey post hoc tests. Figure S2. Seasonal variation in the maximum distance to night enclosures (max_dist, km) of (a) cattle and (b) goat herds from Ankilibory $(A K)$, Efoetse (EF), Andremba (AD), Miarintsoa (MI), and the transhumance cattle herds (C-T). Data are presented for the early dry season (EDS), the late dry season (LDS), and the rainy season (RS). Medians (black lines inside the boxes), interquartile ranges (width of the boxes representing the middle $50 \%$ of data), total data ranges (whiskers), and outliers (black dots) are shown. Different letters above and underneath the box plots indicate village differences at $p \leq 0.05$ according to Tukey post hoc tests. Note the different scaling of $Y$-axes in a and b. Figure S3. Seasonal variation in the linear distance between the night corral of (a) cattle and (b) goat herds from Ankilibory (AK), Efoetse (EF), Andremba (AD), Miarintsoa (MI), and the transhumance cattle herds (C-T) to the nearest visited water point (dist_water, km). Data are presented for the early dry 
season (EDS), the late dry season (LDS), and the rainy season (RS). Medians (black lines inside the boxes), interquartile ranges (width of the boxes representing the middle $50 \%$ of data), total data ranges (whiskers), and outliers (black dots) are shown. Different letters above and underneath the box plots indicate village differences at $p \leq 0.05$ according to Tukey post hoc tests. Note the different scaling of $Y$-axes in a and b. Figure S4. Grazing itineraries of studied cattle herds from Ankilibory between November 2011 and November 2013. Different line colours are used for different seasons (see legend). Figure S5. Grazing itineraries of studied goat herds from Ankilibory between November 2011 and November 2013. Different line colours are used for different seasons (see legend). Figure S6. Grazing itineraries of studied cattle herds from Efoetse between November 2011 and November 2013. Different line colours are used for different seasons (see legend). Figure S7. Grazing itineraries of studied goat herds from Efoetse between November 2011 and November 2013. Different line colours are used for different seasons (see legend). A temporary medium-distance dislocation of one herd in 2012 is not shown on the map. Figure S8. Grazing itineraries of studied cattle herds from Andremba between November 2011 and November 2013. Different line colours are used for different seasons (see legend). A temporary medium-distance dislocation of one herd in 2012 is not shown on the map. Figure S9. Grazing itineraries of studied cattle herds from Andremba between November 2011 and November 2013. Different line colours are used for different seasons (see legend). Figure S10. Grazing tineraries of studied cattle herds from Miarintsoa between November 2011 and November 2013. Different line colours are used for different seasons (see legend). A temporary 'inverse' transhumance movement of one herd in 2012 and in 2013 is not shown on the map. Figure S11. Grazing itineraries of studied goat herds from Miarintsoa between November 2011 and November 2013. Different line colours are used for different seasons (see legend). Figure S12. Grazing itineraries of studied cattle herds from Ankilibory and Efoetse during times of transhumance in 2012 and 2013. Figure S13. Proportion of daily resting time (\%) of cattle herds from Ankilibory (AK), Efoetse (EF), Andremba (AD), Miarintsoa (MI), and the transhumance cattle herds (C-T) spent on different land cover classes (a) and share of these land cover classes (\%) within the grazing utilization zones around the four villages and the transhumance zone of coastal cattle herds (b). Data are shown for the early dry season (EDS), the late dry season (LDS), and the rainy season (RS). Figure S14. Proportion of daily walking time (\%) of cattle herds from Ankilibory (AK), Efoetse (EF), Andremba (AD), Miarintsoa (MI), and the transhumance cattle herds (C-T) spent on different land cover classes (a) and share of these land cover classes (\%) within the grazing utilization zones around the four villages and the transhumance zone of coastal cattle herds (b). Data are shown for the early dry season (EDS), the late dry season (LDS), and the rainy season (RS).

Figure S15. Proportion of daily resting time (\%) of goat flocks from Ankilibory (AK), Efoetse (EF), Andremba (AD), and Miarintsoa (MI) spent on different land cover classes (a) and share of these land cover classes (\%) within the grazing utilization zones around the four villages (b). Data are shown for the early dry season (EDS), the late dry season (LDS), and the rainy season (RS). Figure S16. Proportion of daily walking time (\%) of goat flocks from Ankilibory (AK), Efoetse $(\mathrm{EF})$, Andremba (AD), and Miarintsoa (MI) spent on different land cover classes (a) and share of these land cover classes (\%) within the grazing utilization zones around the four villages (b). Data are shown for the early dry season (EDS), the late dry season (LDS), and the rainy season (RS). (DOCX $7101 \mathrm{~kb}$ )

Additional file 2: Table S1. Duration of cattle and goat herds resting (near villages/corrals) during noontime. (DOCX $18 \mathrm{~kb}$ )

\section{Competing interests}

The authors declare that they have no competing interests.

\section{Authors' contributions}

TF collected and analysed the data and drafted the manuscript. ES conceived the study, participated in its design, and helped draft the manuscript. Both authors read and approved the final manuscript.

\section{Authors' information}

TF is a postdoctoral fellow at the Section Animal Husbandry in the Tropics and Subtropics at the University of Kassel (Germany). The manuscript is part of his doctoral thesis on 'Interrelatedness of grazing livestock with vegetation parameters and farmers' livelihoods in the Mahafaly region, southwestern Madagascar'. ES is a professor of the Animal Husbandry in the Tropics and
Subtropics and head of the above-mentioned section at the University of Kassel and the University of Göttingen.

\section{Acknowledgements}

This study was part of the SuLaMa project funded by the German Federal Ministry of Education and Research (BMBF, FKZ: 01LL0914C). The authors are grateful to the staff of the regional WWF office in Toliara and the project members, in particular the drivers and socio-organizers, for their great support during the fieldwork. Special thanks go to Fidgerald Ramananoro, Ononamandimby Antsonantenainarivony, and our local assistants for sustaining the data collection in the periods of absence from Madagascar and Katja Brinkmann for providing an initial version of the digital land cover classification map as well as Regina Roessler, Alexandra zum Felde, and an anonymous reviewer for the helpful comments on earlier versions of this paper. We would like to particularly highlight Pascal Fust for his willingness to intensively discuss relevant issues concerning analytical procedures and study outcome, and we are grateful for the very helpful comments of an anonymous reviewer on the initial version of this manuscript. Finally, we thank the people and above all the herd owners and herders from Andremba, Ankilibory, Efoetse, and Miarintsoa for their hospitality and permission to work with their animals.

Received: 15 September 2015 Accepted: 3 March 2016

Published online: 18 March 2016

\section{References}

Adriansen, H.K. 2008. Understanding pastoral mobility: The case of Senegalese Fulani. The Geographical Journal 174(3): 207-222. doi:10.1111/j.1475-4959. 2008.00278.x.

Ministère de I'Environnement \& Association Nationale pour la Gestion des Aires Protégées. 1999. Etude pour l'élaboration d'un plan d'aménagement et de gestion au niveau de la Réserve Naturelle Intégrale de Tsimanampetsotsa: diagnostic physico-bio-écologique. Madagascar: Antananarivo.

Akasbi, Z., J. Oldeland, J. Dengler, and M. Finckh. 2012. Analysis of GPS trajectories to assess goat grazing pattern and intensity in Southern Morocco. The Rangeland Journal 34(4): 415-427. doi:10.1071/RJ12036.

Amnesty International. 2013. Amnesty International Report 2013. London, UK: The state of the world's human rights.

Andrew, M.H. 1988. Grazing impact in relation to livestock watering points. Trends in Ecology \& Evolution 3(12): 336-339. doi:10.1016/0169-5347(88)90090-0.

Ayantunde, A.A., S. Fernández-Rivera, P.H.Y. Hiernaux, H. van Keulen, H.M.J. Udo, and M. Chanono. 2000. Effect of nocturnal grazing and supplementation on diet selection, eating time, forage intake and weight changes of cattle. Animal Science 71(2): 333-340.

Ayantunde, A.A., S. Fernández-Rivera, P.H. Hiernaux, H. van Keulen, and H.M.J. Udo. 2002. Day and night grazing by cattle in the Sahel. Journal of Range Management 55(2): 144-149. doi:10.2307/4003350.

Baker, L.E., and M.T. Hoffman. 2006. Managing variability: Herding strategies in communal rangelands of semiarid Namaqualand, South Africa. Human Ecology 34(6): 765-784. doi:10.1007/s10745-006-9036-y.

Battistini, R. 1966. Géographie humaine de la plaine côtière Mahafaly. L'Homme 6(2): 131-132.

Brinkmann, K., N. Fananbinantsoa, R.Y. Ratovonamana, and A. Buerkert. 2014. Deforestation processes in southwestern Madagascar during the past 40 years: What can we learn from settlement characteristics? Agriculture, Ecosystems \& Environment 195: 231-243. doi:10.1016/j.agee.2014.06.008.

Brottem, L., M.D. Turner, B. Butt, and A. Singh. 2014. Biophysical variability and pastoral rights to resources: West African transhumance revisited. Human Ecology 42(3): 351-365. doi:10.1007/s10745-014-9640-1.

Butt, B. 2010a. Pastoral resource access and utilization: Quantifying the spatial and temporal relationships between livestock mobility, density and biomass availability in Southern Kenya. Land Degradation \& Development 21(6): 520-539. doi:10.1002/ldr.989.

Butt, B. 2010b. Seasonal space-time dynamics of cattle behavior and mobility among Maasai pastoralists in semi-arid Kenya. Journal of Arid Environments 74(3): 403-413. doi:10.1016/j.jaridenv.2009.09.025.

Casse, T., A. Milhøj, S. Ranaivoson, and J.R. Randriamanarivo. 2004. Causes of deforestation in southwestern Madagascar: What do we know? Forest Policy and Economics 6(1): 33-48. doi:10.1016/S1389-9341(02)00084-9. 
Coppolillo, P.B. 2001. Central-place analysis and modeling of landscape-scale resource use in an East African agropastoral system. Landscape Ecology 16(3): 205-219. doi:10.1023/A:1011148503303.

Fafchamps, M., and C. Moser. 2003. Crime, isolation and law enforcement. Journal of African Economies 12(4): 625-671. doi:10.1093/jae/12.4.625.

FAO, and AGAL. 2005. Livestock Sector Brief - Madagascar. Rome, Italy: Livestock Sector Brief (LSB)

FAOSTAT, 2014. FAO estimate. http://faostat.fao.org/site/573/default.aspx\#ancor. Accessed 8/28/2014.

Fauroux, E. 2004. Voleurs de bœufs, état et paysans dans l'ouest et le sud-ouest malgaches. Studia Africana 15: 16-45.

Fauroux, E. 1989a. Bœufs et pouvoirs: Les éleveurs du sud-ouest et de l'ouest malgaches. Politique Africaine 34: 63-73.

Fauroux, E. (ed.). 1989b. Le bouf et le riz dans la vie économique et sociale Sakalava de la vallée de la Maharivo, 3-295, Aombe 2.

Feldt, T. 2015. Interrelatedness of grazing livestock with vegetation parameters and farmers' livelihoods in the Mahafaly region, southwestern Madagascar. PhD thesis, University of Kassel, Germany.

Fenn, M.D. 2003. The spiny forest ecoregion. In The natural history of Madagascar, ed. S.M. Goodman and J.P. Benstead, 1525-1530. Chicago, USA, London, UK: The University of Chicago Press.

Fieloux, M., and L. Rakotomalala. 1987. Développement agricole et transformation des territoires pastoraux. Aombe 1: 61-83.

Goodman, S.M., and J.P. Benstead (eds.). 2003. The natural history of Madagascar. Chicago, USA, London, UK: The University of Chicago Press.

Hanisch, S., C. Lohrey, and A. Buerkert. 2015. Dewfall and its ecological significance in semi-arid coastal south-western Madagascar. Journal of Arid Environments 121: 24-31. doi:10.1016/j.jaridenv.2015.05.007.

Hiernaux, P., E. Mougin, L. Diarra, N. Soumaguel, N. Lavenu, Y. Tracol, and M. Diawara. 2009. Sahelian rangeland response to changes in rainfall over two decades in the Gourma region, Mali. Journal of Hydrology 375(1-2): 114-127. doi:10.1016/j.jhydrol.2008.11.005

Hoerner, J.M. 1982. Les vols de bœufs dans le Sud Malgache. Madagascar revue de géographie 41: 85-105.

Ignace, R. 2010. L'insécurité rurale liée au vol de bœufs: quelques propositions de solution. TALOHA 19. http://www.taloha.info/document.php?id=906. Accessed 11/11/2014.

INSTAT. 2014. Population \& démographie. http://instat.mg/category/population/. Accessed 11/3/2014.

ISS. 2010. Advocating for safe movement as a climate change adaptation strategy for pastoralists in the Horn and East Africa. Nairobi, Kenya: Institute of Security Studies (ISS), UN-OCHA, UNEP and IOM. http://reliefweb.int/sites/reliefweb. int/files/resources/8E4A32AF1BCEE2544925775800065831-Full_Report.pdf. Accessed 15/1/2016.

Jury, M.R. 2003. The climate of Madagascar. In The natural history of Madagascar ed. S.M. Goodman and J.P. Benstead, 75-87. Chicago, USA, London, UK: The University of Chicago Press.

Kaufmann, J.C. 1998. The cactus was our kin: Pastoralism in the spiny desert of Southern Madagascar. In Changing nomads in a changing world, ed. J. Ginat and A.M. Khazanov, 124-142. Brighton, UK: Sussex Academic Press.

Kaufmann, J.C. 2004. Prickly pear cactus and pastoralism in Southwest Madagascar. Ethnology 43(4): 345-361. doi:10.2307/3774032.

Kaufmann, J.C., and S. Tsirahamba. 2006. Forests and thorns: Conditions of change affecting Mahafale pastoralists in southwestern Madagascar. Conservation \& Society 4(2): 231-261.

Krätli, S., Hesse, C., Swift, J., Monimart, M., Jalloh, B. 2014. Securing pastoral mobility in Sahel. A Question of Development No 10, August 2014. French Development Agency, Paris. http://www.afd.fr/webdav/site/afd/shared/ PUBLICATIONS/RECHERCHE/Scientifiques/Question-developpement/10-VAquestion-developpement.pdf. Accessed 15/1/2016.

Krätli, S., Kaufmann, B., Roba, H., Hiernaux, P., Li, W., Easdale, M., Hülsebusch, C., 2015. A house full of trap doors. Identifying barriers to resilient drylands in the toolbox of pastoral development. Discussion paper, International Institute for Environment and Development, London and Edinburgh, UK.

Leff, J. 2009. Pastoralists at war: Violence and security in the Kenya-SudanUganda border region. International Journal of Conflict and Violence 3(2): 188-203.

Little, P.D., and J.G. McPeak. 2014. Resilience and pastoralism in Africa south of the Sahara, with a particular focus on the horn of Africa and the Sahel, West Africa. 2020 Conference Paper 9, Washington, DC, USA.
Morat, P. 1973. Les savanes du sud-ouest de Madagascar. Paris, France: Mémoire ORSTOM 68.

Moritz, M., Z. Galehouse, Q. Hao, and R.B. Garabed. 2012. Can one animal represent an entire herd? Modeling pastoral mobility using GPS/GIS technology. Human Ecology 40(4): 623-630. doi:10.1007/s10745-012-9483-6.

Moritz, M., I.M. Hamilton, A.J. Yoak, P. Scholte, J. Cronley, P. Maddock, and H. Pi. 2015. Simple movement rules result in ideal free distribution of mobile pastoralists. Ecological Modelling 305: 54-63. doi:10.1016/j.ecolmodel.2015.03.010.

Neudert, R., J. Götter, J. Andriamparany, and M. Rakotoarisoa. 2015. Income diversification wealth, education and well-being in rural south-western Madagascar: Results from the Mahafaly region. Development Southern Africa 32(6): 758-784. doi:10.1080/0376835X.2015.1063982.

Niamir-Fuller, M. (ed.). 1999a. Managing mobility in African rangelands: The legitimization of transhumance. London, UK: Intermediate Technology Publications.

Niamir-Fuller, M. 1999b. Conflict management and mobility among pastoralists in Karamoja, Uganda. In Managing mobility in African rangelands: The legitimization of transhumance, ed. M. Niamir-Fuller, 149-183. London, UK: Intermediate Technology Publications.

Ouédraogo-Koné, S., C.Y. Kaboré-Zoungrana, and I. Ledin. 2006. Behaviour of goats, sheep and cattle on natural pasture in the sub-humid zone of West Africa. Livestock Science 105(1-3): 244-252. doi:10.1016/j.livsci.2006.06.010.

SuLaMa, Projet. 2011. Diagnostic participatif de la gestion des ressources naturelles sur le plateau Mahafaly. Toliara, Madagascar: Rapport final.

Rabeniala, R., L.I.B. Raoliarivelo, H.N. Masezamana, J.H. Andrianarisoa, and R.J. Randriamalala. 2009. Gestion du pâturage pour le cheptel de petits ruminants (ovins et caprins) dans une zone semi-aride du district de Toliara II. Toliara, Madagascar: ESAPP Project Report.

Ranaivoarivelo, N., and P. Milleville. 2001. Exploration pastorale des savanes de la région de Sakaraha (Sud-Ouest de Madagascar). In Sociétés paysannes, transitions agraire et dynamiques écologiques dans le sud-ouest de Madagascar, ed. S. Razanaka, M. Grouzis, P. Milleville, B. Moizo, and C. Aubry, 181-197. Antananarivo, Madagascar: Actes de I'Atelier CNRE-IRD.

Randolph, T.F., E. Schelling, D. Grace, C.F. Nicholson, J.L. Leroy, D.C. Cole, M.W. Demment, A. Omore, J. Zinsstag, and M. Ruel. 2007. Role of livestock in human nutrition and health for poverty reduction in developing countries. Journal of Animal Science 85(11): 2788-2800. doi:10.2527/jas.2007-0467.

Rasambainarivo, J.H., and N. Ranaivoarivelo. 2006. Madagascar. FAO Country Pasture/Forage Resource Profiles, Antananarivo, Madagascar.

Razanaka, S.J. 1996. Répartition des espèces xérophiles dans le sud-ouest de Madagascar. In Biogéographie de Madagascar - Biogeogra-phy of Madagascar, ed. W.R. Lourenço, 171-176. Paris, France: ORSTOM Éditions.

Samuels, M.l., N. Allsopp, and R.S. Knight. 2007. Patterns of resource use by livestock during and after drought on the commons of Namaqualand, South Africa. Journal of Arid Environments 70(4): 728-739. doi:10.1016/j.jaridenv.2006.11.006.

Schilling, J., F.E.O. Opiyo, and J. Scheffran. 2012. Raiding pastoral livelihoods: Motives and effects of violent conflict in north-western Kenya. Pastoralism: Research, Policy and Practice 2(25): 25. doi:10.1186/2041-7136-2-25.

Schlecht, E., P. Hiernaux, I. Kadaouré, C. Hülsebusch, and F. Mahler. 2006. A spatiotemporal analysis of forage availability and grazing and excretion behaviour of herded and free grazing cattle, sheep and goats in Western Niger. Agriculture, Ecosystems \& Environment 113(1-4): 226-242. doi:10.1016/j.agee.2005.09.008.

Schlecht, E., U. Dickhoefer, E. Gupertsberger, and A. Buerkert. 2009. Grazing itineraries and forage selection of goats in the Al Jabal al Akhdar mountain range of northern Oman. Journal of Arid Environments 73(3): 355-363. doi:10.1016/j.jaridenv.2008.10.013.

Scoones, I. 1995. Exploiting heterogeneity: Habitat use by cattle in dryland Zimbabwe. Journal of Arid Environments 29(2): 221-237. doi:10.1016/S01401963(05)80092-8

Swallow, B. 1994. The role of mobility within the risk management strategies of pastoralists and agro-pastoralists. Gatekeeper Series No. 47, London, UK.

Tengö, M., K. Johansson, F. Rakotondrasoa, J. Lundberg, J.A. Andriamaherilala, J.-A. Rakotoarisoa, and T. Elmqvist. 2007. Taboos and forest governance: Informal protection of hot spot dry forest in southern Madagascar. Ambio 36(8): 683-691. doi:10.1579/0044-7447(2007)36[683:TAFGIP]2.0.CO;2.

Thrash, I., and J.F. Derry. 1999. The nature and modelling of piospheres: A review. Koedoe 42(2): 73-94. doi:10.4102/koedoe.v42i2.234.

Toutain, B., M.N. de Visscher, and D. Dulieu. 2004. Pastoralism and protected areas lessons learned from Western Africa. Human Dimensions of Wildlife 9(4): 287-295. doi:10.1080/108071200490505963.

Tsirahamba, S., and J.C. Kaufmann. 2008. Absence of shade: Deforestation in Mahafale forest-pastures. In Greening the great red island: Madagascar in 
nature and culture, ed. J.C. Kaufmann, 179-196. Pretoria, South Africa: Africa Institute of South Africa.

Turner, M.D. 1999. The role of social networks, indefinite boundaries and political bargaining in maintaining the ecological and economic resilience of the transhumance systems of Sudano-Sahelian West Africa. In Managing mobility in African rangelands: The legitimization of transhumance, ed. M. Niamir-Fuller, 97-123. London, UK: Intermediate Technology Publications.

Turner, M.D., and P. Hiernaux. 2002. The use of herders' accounts to map livestock activities across agropastoral landscapes in semi-arid Africa. Landscape Ecology 17(5): 367-385. doi:10.1023/A:1021238208019.

Turner, M.D., A.A. Ayantunde, K.P. Patterson, and E.D. Patterson III. 2011. Livelihood transitions and the changing nature of farmer-herder conflict in Sahelian West Africa. Journal of Development Studies 47(2): 183-206. doi:10.1080/00220381003599352.

Turner, M.D., J.G. McPeak, and A. Ayantunde. 2014. The role of livestock mobility in the livelihood strategies of rural peoples in semi-arid West Africa. Human Ecology 42(2): 231-247. doi:10.1007/s10745-013-9636-2.

Vetter, S. 2005. Rangelands at equilibrium and non-equilibrium: Recent developments in the debate. Journal of Arid Environments 62(2): 321-341. doi:10.1016/j.jaridenv.2004.11.015.

Wüstefeld, M. 2004. Bedeutung der Rinder für die Ernährungssicherung im semiariden Süden Madagaskars. Farming \& Rural Systems Economics 62. Weikersheim, Germany: Margraf Publishers GmbH.

\section{Submit your manuscript to a SpringerOpen ${ }^{\odot}$ journal and benefit from:}

- Convenient online submission

- Rigorous peer review

- Immediate publication on acceptance

- Open access: articles freely available online

- High visibility within the field

- Retaining the copyright to your article

Submit your next manuscript at $\gg$ springeropen.com 